\title{
Isolation, Characterization and Screening of Anticancerous L- Asparaginase Producing Microbes from Costal Regions
}

\author{
Sanjotha .G \\ Department of Biotechnology, Government arts and science college Karwar, Karnataka, India

\begin{abstract}
L-asparaginase is an extracellular enzyme that has attracted much attention because, it has highly potential anti-cancerous activity. In the present study, four soil samples each were collected from different areas in and around the karwar regions, Karnataka, India. Out of 16 isolates three bacterial strains (CB1, CB2, MB) isolated from costal and mangrove ecosystem showed maximum L-Asparaginase production than estuarine and terrestrial ecosystems and three actinomycetes (CA, MA, TA) isolated from costal, mangrove and terrestrial ecosystems showed potential L-Asparaginaseproduction than estuarine ecosystems on modified M9 medium. Selected isolates were characterized by biochemical tests.
\end{abstract}

Keywords: L-Asparaginase, Anticarcinogenic, karwar, Bacteria, Actinomycetes

\section{INTRODUCTION}

Cancer has emerged as one of the major cause for human suffering with unprecedented morbidity and mortality. There were an estimated 12.7 million cancer cases around the world in 2008, out of these 6.6 million cases were in men and 6.0 million in women. This number is expected to increase to 21 million by 2030 (IAEA Report, 2010). Cancer may be defined as unnecessary tissue growth that results from an imbalance between cell division and apoptosis, (programmed cell death); due to various genetic and epigenetic alterations. Cancer cells are also divided in to benign and metastatic. Leukemia's are neoplasms of hematopoietic cells that proliferate initially in the bone, spleen, lymph nodes and later in other tissues. Acute myeloid leukaemia (AML), chronic lymphoblastic leukaemia (CLL) and hairy cell leukaemia in adults are observed to increase in incidence with age, especially in the sixties and seventies [1].

Many numbers of enzymes have been used as effective therapeutic agent against many kinds of cancer in man [2]. L-asparaginase attracted much attention because, it is highly suitable for treatment of acute lymphoblastic leukemia (mainly in children), Hodgkin disease, acute myelocytic leukemia, acute myelomonocytic leukemia, chronic lymphocytic leukemia, lymphosarcoma treatment, reticulosarcom and melanosarcoma [3, 4]and as food processing aid to reduce the acrylamide formation during frying of starchy foods at high temperature. In lymphocytic leukemia cells are not capable of synthesizing L-asparagine and they rely on the exogenous sources to get L-asparagine [5]. On the contrary, normal cells are protected from L-asparagine starvation due to their ability to generate this essential amino acid [6]. L-asparaginase is known to act by hydrolysing the Lasparagine into aspartic acid and ammonia. Hydrolysis proceeds in two steps via a beta- acyl enzyme as intermediate [2], causing deficiency of the amino acid for cancer cells, whereby it limits the growth of cancerous cell [7].

\subsection{L-Asparaginase}

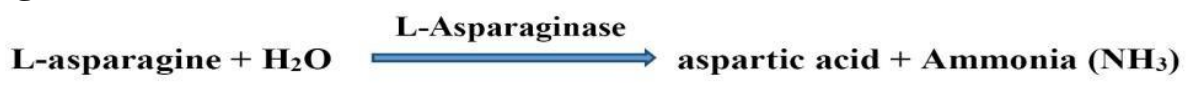

L-asparaginase is a wide spread enzyme, relatively found in many microorganisms for example, Enterobacter aerogenes, Aspergillus terreus[8], Fusarium equiseti[9], Pseudomonas aeruginosa[10], Bacillus subtilis[11], Pyrococcusfuriosus[12], Enterobacter cloaceae, serratiamarcescens[13] etc. The enzymes obtained from bacteria like E.coli and Erwinia have been used in the treatment of acute lymphoblasic leukemia [14]. However due to prolonged intake of drugs causes an anaphylactic reactions in man. Therefore it is necessary to screen novel strains which are able to produce high yield of L-asparaginase [15]. 
Marine biosphere is one of the richest of earth's innumerable habitats and yet is one of the least characterized. Because of the diversity and scale, it offers enormous opportunities for non-destructive exploitation within many facets of modern biotechnology [16]. Most of the Marine microorganisms have potential source of bioactive compounds [17, 18]. Among these, Bacteria have gained special importance in production of antibiotics and secondary metabolites $[19,20]$.The present study was carried out to explore the soil and marine sources for isolation of microbes. Because, there is a continual need to find out newer microbial sources to obtain high-yielding L-asparaginase producing strains, which could be of use to human.

\section{MATERIALS AND MeTHOdS}

\subsection{Sample Collection}

Four soil samples were collected from different areas at a depth of 15 to $20 \mathrm{~cm}$ in and around the karwar regions, Karnataka, India. The location of sample collection includes costal, estuarine, mangrove and terrestrial ecosystems. The samples were collected into a sterile polythene bags and carried to laboratory for further microbial analysis.

\subsection{Isolation of Microorganisms}

All the soil samples were treated for bacterial as well as actinomycetes by serial dilution method. Among four samples each two samples were used for bacterial isolation by using nutrient agar medium [21] with nystatin $(50 \mu \mathrm{g} / \mathrm{mL})$ to avoid fungal contamination, inoculated agar plates were incubated at $37^{\circ} \mathrm{C}$ for 24 hours and two samples were used for isolation of actinomycetes by using Starch casein agar (SCA) medium with Streptomycin $(20 \mu \mathrm{g} / \mathrm{ml})$ and cycloheximide $(50 \mu \mathrm{g} / \mathrm{ml})$ in order to retard the growth of bacteria and fungi. All the plates were incubated at $37^{\circ} \mathrm{C}$ for 6 days. Colonies obtained were further purified and maintained in nutrient agar slants and SCA plates.

\subsection{Screening for L-Asparaginase Production by Plate Method Assay}

The purified 16 isolates were screened for L-Asparaginase production by rapid plate method by using modified M-9 medium. [22]. The medium contained Na2HPO4.2H2O, $6.0 \mathrm{~g}$; $\mathrm{KH} 2 \mathrm{PO} 4,3.0 \mathrm{~g}$; NaCl, 0.5 g; L-Asparagine, $10.0 \mathrm{~g}$; $1 \mathrm{~mol}-\mathrm{MgSO} 4.7 \mathrm{H} 2 \mathrm{O}, 2.0 \mathrm{ml}$; $0.1 \mathrm{M}$ solution ofCaCl2.2H2O, $1.0 \mathrm{ml}$; $20 \%$ glucose stock, $10.0 \mathrm{ml}$; agar $20.0 \mathrm{~g}$. per liter of distilled water. The medium was supplemented with $0.005 \%$ phenol red dye (prepared inethanol) and the $\mathrm{pH}-6.8$. Plates were then incubatedat $35^{\circ} \mathrm{C}$ for 24 hrs. L-Asparaginase producing colonies were selected on the basis of formation of pink color zone around the colonies. Out of 16 isolates three bacterial (CB1, CB2, MB) and three actinomycetes (CA, MA, TA) colonies showed potential L- aparaginase production. However these organisms did not form any pink color zone in control M-9 medium without L-Asparagin. This indicates that the formation of pink zone is due to production of L-asparaginase.

\subsection{Biochemical Characterization of Isolates}

Morphological characters such as shape and color of both bacterial as well as actinimycetes colonies were determined. Grams staining and motility testing by hanging drop method were also performed. Isolates were biochemically analyzed for the activities of oxidase, catalase, MR-VP test, indole production, hydrogen sulphide test, nitrate reduction, citrate utilization, melanoid production test using Waksman medium at an incubation temperature of $37^{\circ} \mathrm{C}$ for 4 days for the detection of pigment producing property of isolates. Gelatin liquefaction test was carried out in nutrient gelatin at an incubation temperature of $37^{\circ} \mathrm{C}$ for $24-48$ hours, acid production test was carried out in glucose nutrient broth at an incubation temperature of $20^{\circ} \mathrm{C}$ for 15 days. The results were compared with Bergey's Manual of Systematic Bacteriology and standard International Streptomyces Project (ISP) procedure.

\section{RESUltS AND DiSCUSSION}

In present study, four soil samples includes costal, estuarine, mangrove and terrestrial ecosystems were collected from different regions of karwar were inoculated on nutrient medium for bacteria and starch casein agar for actinimycetes. Bacterial isolates after incubation showed white, yellow colored colonies on nutrient agar medium and actinomycetes showed grey colored colonies on starch casein agar medium (fig.2). These isolates were used for screening of 1-asparaginase production, by using modified M-9 medium. The medium contained asparagine with phenol red as an indicator (fig.3). Out of 16 isolates three bacterial (CB1, CB2, MB) and three (CA, MA, TA) actinomycetes were showed 
potential L-asparaginase production by forming pink color zone around colonies on the medium (fig.1). These strains were taken for biochemical characterization. Morphology and Biochemical characteristics of both bacteria and actinomycetes are illustrated in table no 1,2 and 3.
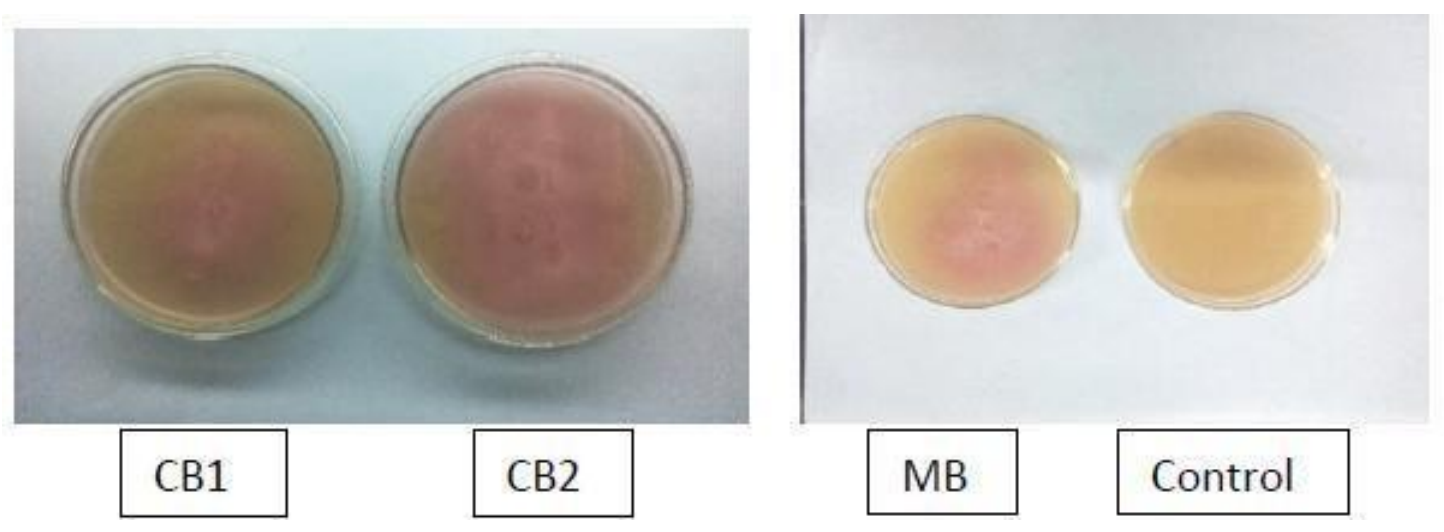

Figure1. Isolation and screening of L-Asparaginase producing Bacteria on modified M9 media using L-Asparagine and phenol red indicator

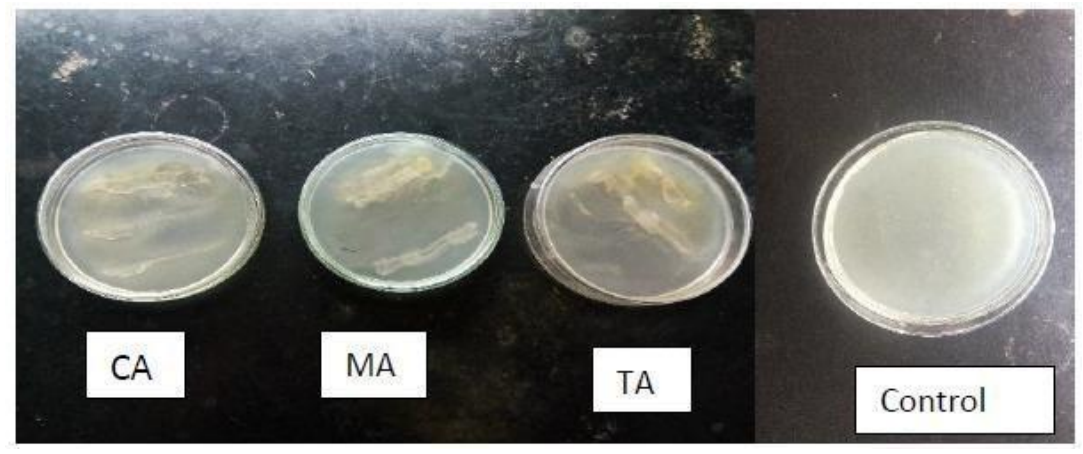

Figure2. Isolation and screening of L-Asparaginase producing actinomycetes on starch casein agar (SCA) media, showing gray colored colonies
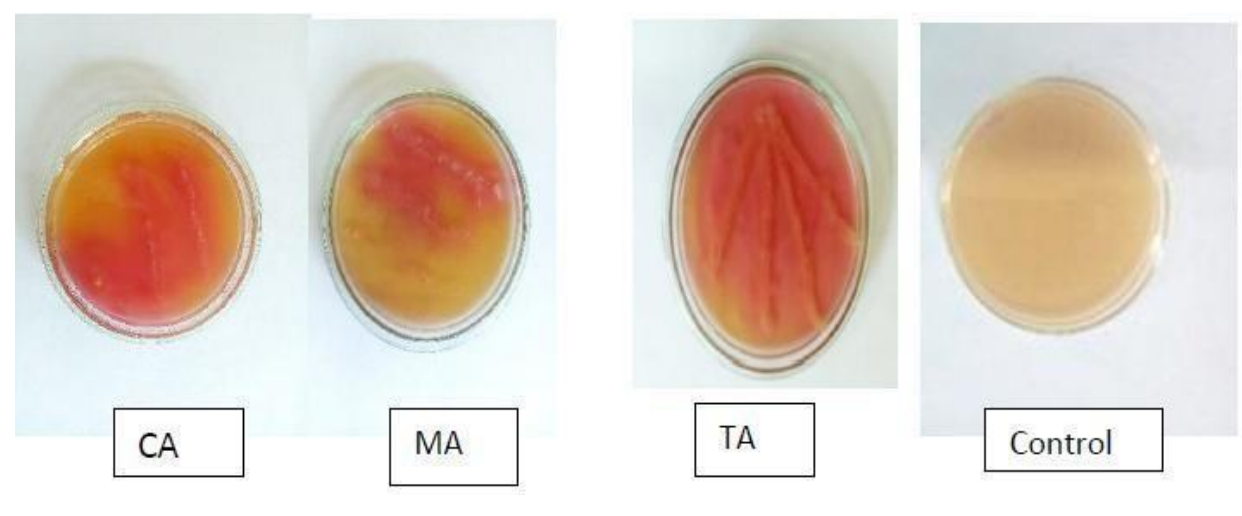

Figure3. Screening of L-Asparaginase producing actinomycetes on modified M9 media, showing pink color zone

Table1. Morphology and cultural characteristics Of L-asparaginase producing bacterial isolates

\begin{tabular}{|c|c|l|l|}
\hline Bacterial isolate designation & Gram staining & shape & Organism \\
\hline CB1 & + ve & Rods & Bacillus sp \\
\hline CB2 & $-v e$ & Short rods & Pseudomonas sp. \\
\hline MB & -ve & Short rods & Pseudomonas sp \\
\hline
\end{tabular}

Table2. Biochemical Studies of Bacterial isolates

\begin{tabular}{|c|l|l|l|l|l|l|}
\hline Bacterial isolate designation & Indole & Methyl red & Vogues Proskeur & Citrate & Catalase & Oxidase \\
\hline CB1 & $-\mathrm{ve}$ & $-\mathrm{ve}$ & $-\mathrm{ve}$ & $+\mathrm{ve}$ & $+\mathrm{ve}$ & $+\mathrm{ve}$ \\
\hline CB2 & $-\mathrm{ve}$ & $+\mathrm{ve}$ & $-\mathrm{ve}$ & $+\mathrm{ve}$ & $+\mathrm{ve}$ & $+\mathrm{ve}$ \\
\hline MB & $-\mathrm{ve}$ & $-\mathrm{ve}$ & $-\mathrm{ve}$ & $+\mathrm{ve}$ & $+\mathrm{ve}$ & $+\mathrm{ve}$ \\
\hline
\end{tabular}


Table3. Biochemical studies of Actinomycetes

\begin{tabular}{|l|l|c|c|c|}
\hline S.No & Biochemical Characterization & \multicolumn{2}{|c|}{ Isolates } \\
\hline & & CA & MA & TA \\
\hline 1 & Melanoid production Test & + & + \\
\hline 2 & Nitrate reduction test & + & + & + \\
\hline 3 & Acid production test & + & + & - \\
\hline 5 & Hydrogen sulphide production test & - & - & - \\
\hline
\end{tabular}

\section{CONCLUSION}

From this work, it was clearly shows that costal and mangrove ecosystem soil samples can provide a potential source of L-asparaginase producing bacteria when compared to estuarine and terrestrial ecosystem soils samples and costal, mangrove and terrestrial ecosystem soil samples exhibit a potential source of actinomyctese when compared to estuarine soil samples. However in future optimization of these isolates will be done to increase the potentiality to produce L-asparaginase.

\section{ACKNOWLEDGEMENT}

The authors are grateful to University Grants Commission New Delhi, India for providing the financial support and Govt. arts and Science College, karwar, Karnataka, India for providing laboratory and technical support.

\section{REFERENCES}

[1] Siegel R., Ward E., Brawley O., Jemal A., Cancer statistics. CA: a cancer journal for clinicians, 2(17): 25. (2011)

[2] Siddalingeshwara K.G., Lingappa, K., "Key fermentation factors for the synthesis of L-asparaginase -an anti-tumor agent through SSF methodology." Pharma science monitor, 1(1). (2010)

[3] Stecher AL., Morgantetti P., De Deus., Polikarpov I. andAbrahao- NetoJ., Stability of Lasparaginase-an enzyme used in Leukemia treatment, "Pharmaceut.ActaHelv", 74, ,1-9. (1999)

[4] Verma N., Kumar K., Kaur G.andAnand S.,L-asparaginase: a promising chemotherapeutic agent, "Critical Review in Biotechnology", 27, 45-62. (2007).

[5] Lee SM., Wroble MH., Ross JT., L-asparaginase from Erwiniacarotovora-an improved recovery and purification processusing affinity chromatography, "Appl. Biochem. Biotechnol", 22, 1-11. (1989).

[6] Duval M., Suciu S., Ferster A., Rialland X., Nelken B., Lutz P., Benoit Y., Robert A., Manel AM., Vilmer E., Otten J., Phillippe N., Comparison of Escherichia coli Asparaginase with Erwiniaasparaginase in the treatment of childhood lymphoid malignancies. Results of a randomized European organization for research and treatment of cancerchildren's leukemia group phase 3 trails. "Blood", 99, 2734-2739, (2002).

[7] Kotzia G.A., Labrou N.E., L-Asparaginase from ErwiniaChrysanthemi 3937: Cloning, expression and characterization. Journal of biotechnology; 127(4): 657-69. (2007)

[8] Sarquis M.I., Oliveira E.M., Santos A.S., Costa G., " A Novel and sensitive agar plug assay for screening of asparaginase producing endophytic fungi from Aegle marmelos." Man Inst Oswaldo Cruz, 99(5), 489. (2004).

[9] Hosamani R and Kaliwal, B.B.,"Isolation, Molecular Identification and Optimization of Fermentation Parameters for the Production of L- Asparaginase, An Anticancer Agent By Fusarium Equiseti." International Journal of Microbiology Research, 3(2), 108-119. (2011)

[10] Ashraf A., El-Bessoumy., Mohamed Sarhan., Jehan Mansour., "Production, Isolation, and Purification of L-Asparaginase from Pseudomona aeruginosa 50071 Using Solid-state Fermentation." Journal of Biochemistry and Molecular Biology, 37(4), 387-393. (2004)

[11] Mohammed A., Mazini A.L.,"L-asparaginase activity by various bacteria." Journal of Missan Researches, 4 (7)

[12] Bansal S., Gnaneswari D., Mishra P., Kundu B., "Structural Stability and Functional Analysis of LAsparaginase from Pyrococcusfuriosus.” Biochemistry (Moscow), 75(3), 375-381. (2010).

[13] Agarwal A., Kumar S andVeeranki V.D., "Effect of chemical and physical parameters on the production of L-asparaginase from a newly isolated Serratiamarcescens SK-07." Letters in Applied Microbiology, 52, 307-313(2011). 
[14] Dhevagi $\mathrm{P}$ and Poorani E., "Isolation and characterization of L-asparaginase from marine actinomycetes." Indian Journal of Biotechnology, 5, 514-520. (2006)

[15] Amena S., Vishalakshi N., Prabakar M., Dayanand A., Lingappa K., "Production, Purification and Characterization of L-aspraginase from Streptomyces gulbargensis." Brazilian Journal of Microbiology, 41, 173-178. (2010).

[16] Sabu A., L-Glutaminase production by marine fungi, Ph.D thesis, Cochin University of Science and Technology, Cochin, India (1999).

[17] Lehninger A.L. "Principles of biochemistry", New Delhi: CBS Publishers, , 207-247 (1990).

[18] Trevan M., Boffey S., Goulding KH., Stanbury P., "Biotechnology, the Biological principles", New Delhi, Tata Mc Graw-Hill Publishing Ltd, 155-228. (2004).

[19] Benny P J and Kurup M., L-asparaginase activity in bacteria from esturine sediments and Mollusk, "Indian. J. Mar. Sci” 20, 36-39. (1991)

[20] Okami Y., Marine microorganisms as a source of bioactive agents, "Microb. Ecol", 12, 1, 65-78. (1986)

[21] Waksman S A., Priciples of Soil microbiology. USA: The Williams and Wilkins Co., Baltimore,Md., 2 nd ed.; 894. (1927)

[22] Gulati R., Saxena R K., Gupta R A. Rapid plate assay for screening Lasparaginase producing microorganisms. Lett ApplMicrobiol.; 24, 23, 26 (1997). 